\title{
The Elements of Business Process Change
}

\begin{abstract}
Abebe Walle Meniberu*
Abstract

One of the tools used by governments to bring about organizational transformation is business process change (BPC). The objective of BPC is to bring dramatic changes in the way organizations conduct their business. Though the BPC concept seems to be conceptually appealing, it has been reported by many scholars that BPC comes short of its expectations. This study aimed at identifying and assessing the factors that contribute for successful implementation of BPC projects in organizations of the developing country context. The factors identified as important include the degree to which strategic business process changes are included in the BPC project, level and complexity of problems encountered; the degree to which proposed BPC objectives are being identified and incorporated in these change project plans and are actually derived; and the impact of BPC endeavors on business processes and on the organization. The study developed hypotheses about the BPC implementation process and the test results were found to be consistent with the hypotheses. The result of the study revealed that organizations give little attention to strategic processes critical to the very existence of the organization and employees' empowerment recommended in the BPC literature. While implementing BPC, the most frequent problems seem to be very difficult to address such as communication barriers, the unforeseen magnitude of the BPC effort, and its interruption to operations. Based on findings of the study, conclusions are drawn and recommendations are made for practitioners to focus on success factors such as top management commitment. Well organized BPC project team and plans, focus on outcomes, sufficient resources and fund, well defined communications plan, team spirit and good working environment.
\end{abstract}

Keywords: Business Process Change, Success Factors, BPC Outcomes

http://dx.doi.org/10.4314/ejbe.v5i1.2

*Lecturer, Department of Accounting and Finance, College of Business and Economics, Bahir Dar University, P.O. BOX 532, Telephone +251938883388

Email: abebebdu@gmail.com 


\section{Introduction}

In Sub-Sahara Africa (SSA), since the 1980s significant efforts have been made to reform and transform public management due to governments' difficulties in early diagnosing and rectifying problems, avoiding public sector failure, selecting policy directions, and designing effective and efficient program. As a result, many countries in SSA have been practicing donorinduced public sector reform programs since the 1980s (Antwi, Analoui and Nana-Agyekum, 2008). One of the tools used by some governments in Africa to bring about organizational transformation is business process reengineering (BPR). BPR is meant to bring dramatic changes in the way organizations conduct their business. Literature has confirmed that failures and successes of numerous BPR projects (see for example works of Abdolvand, etal 2008; Ahmad, etal, 2007; Amoroso, 1998; Attaran, 2000; Cheng and Chui, 2008; Hammer and Stanton, 1995; McAdam and Leonard, 1999; and Lockamy and Smith, 1997). It has been widely adopted by private businesses and has been a focus of research since the 1990s and has been researched under different names such as business process reengineering, process improvement, process innovation, business process redesign and business process management (BPM) are terms frequently used interchangeably to represent the phenomenon of business process change (Kettinger and Grover, 1995;Rosemann and Brocke 2010; Hammer 2010). Therefore, for this research purpose, business process change is used throughout this paper as used by scholars Kettinger and Grover (1995). Though BPC has been widely applied by private organizations public organizations also apply it in a similar fashion (Fraguso, 2015; Roberto \& Eleonara, 2015; Thong, Yap, Sea, 2000). In fact such public offices are moving towards the BPC to reform how they do business (Kassahun, 2012). 
The Ethiopian Government, as one of its structural adjustment schemes, has undertaken major structural changes to the civil service since 1993 (Debela, 2011). Hence, the reform of Public Sector Management was initiated with the launch of the Civil Service Reform Program (CSRP) in 1996 (UNDP, 2007). All government offices have undergone through these change projects 'to enhance the capacity of public institutions in Ethiopia and to create an ideal environment for investment and economic growth' (Mengesha and Common, 2007). The CSRP was designed to improve the efficiency, effectiveness, and transparency of public institutions. It included components such as top management system reform sub program; human resource management system reform sub program; service delivery improvement reform sub program; government expenditure and control reform sub program and ethics sub program. In 2001, the Government launched a comprehensive National Capacity Building Program (NCBP), which was designed to strengthen working systems, improve organizational effectiveness, and rapidly develop human resources in the public sector (ibid). Process reengineering (BPR) was introduced in 2003 and applied across Public organizations in Ethiopia as part of the civil service reform program (Gebrekidan, 2011). Again, the Government of Ethiopia embarked on a 5-year national Public Sector Capacity Building Program (PSCAP) in 2004/5 to address major gaps in national capacity (UNDP, 2007).

In the face of the efforts made and the resources and time spent, the implementation of the public sector reform process proved to be problematic and challenging. Few studies that have been conducted on the Ethiopian civil service reform program seem to have reflected a story of total failure (Hailemariam and Brocke, 2011). The much talked about effectiveness, efficiency and speed of delivery of services could not be observed in public 
bodies as can be seen from the different reports (see for example world bank's Implementation Status \& Results Ethiopia Public Sector Capacity Building Program Support Project (P074020) implementation status and results report No. ISR3824) coming out of various offices. Besides a consultancy study conducted by Teklegiorgis and Amare (2007) has reported success stories of BPR about time reduction in provision of license in the Ministry of Trade and Industry of Ethiopia.

The study explores the implementation process of BPC projects in selected government offices in Amhara Regional State, Ethiopia, as cases for the study. The implementation process constitutes the period the BPC project is launched and after that.

\section{Literature Review}

This section represents literature review related to strategic management, performance management, and business process change that is considered relevant for developing a conceptual model.

\subsection{Strategic Process Changes (Process Outcome)}

Business process change projects conducted in different organizations could vary widely in terms of their scope. For example, at times individuals may address processes which have a wider impact on the overall performance of an organization or they may tackle such change efforts which may have an impact on a single process or several processes. Significant numbers of business processes are potential targets for Business process change like customer service, student registration, trade license provision, purchasing, etc. Hammer and Champy (1993) assert that organizations which have successfully 
implemented re-engineering started by asking themselves 'why I do what we do?' Similar questions have to be asked while organizations try to formulate their strategic plan, their mission and vision (Kaplan and Norton, 2008). 'Therefore, re-engineering requires firms to align core processes with their strategic objectives' (Lockamy III and Smith, 1997). Several studies tried to link strategy with BPC (Earl etal, 1995; Lockamy III and Smith, 1997; Kettinger and Teng, 1998; Herzog etal, 2009). It is also reported that (Salman, 2004) the problem of aligning organizational strategy with people, process and technology has been the major factor in conducting a successful BPC in public organizations of developing countries. Hence the construct process outcomes in this research are used to address the degree to which the strategic processes were addressed and the degree to which process outcomes were achieved.

\subsection{BPC Goals and Objectives (Process Performance)}

The foremost objective of BPC is to build organizations where they become more competitive through improvement of quality; reduction of costs and shortened product or service development cycles and these objectives goe to public sector institutions as well (Dagres, 1993; Grover, et al, 1998). Also it has been asserted that BPC can improve the performance of the public sector in a developing country such as Ethiopia (Kassahun, 2012). The distinctive characteristics of BPC efforts constitute a radical redesign of business processes, cross-functional thinking, thinking out of the box, and involves innovative application of information communication technology (Kettinger and Grover, 1995; Tsang, 1993). Furthermore, Hammer (2010) stresses the value added incorporated in the change process. According to Stadler and Elliot (1992) this is to mean that when undertaking such change projects such 
as BPC has to understand timeliness for competitive advantage, resul- oriented mentality, quality product and service any time and place, process-oriented planning for lasting solution, challenging the old ways and proposing new way of doing things, using the right ICT, empowering people and building team spirit on making changes, and setting stretched goals. Hence the goals and objectives addressed in this study are to be used for two constructs such as 'The degree to which organizational outputs (organizational goals and objectives) were included in the BPC plan' and 'the degree to which such organizational desired outputs were achieved'.

\subsection{BPC Implementation Problems}

So much and very huge is the promise to a successful reengineering; so frequent and so devastating are the failures. For example, Hammer and Champy (1993) estimated that between 50 to 70 percent of reengineering efforts failed. For instance Cascio (1993) stated that when organizations announce the introduction of such change efforts, the stock prices of these companies rise and surge when stockholders understand BPC is not a quick fix. In all too many companies, reengineering has been simultaneously a great success and a great failure. ........ 'by now, paradoxical outcomes of this kind have become almost common place' (Eugene, et al, 1994).

Mitigating BPC implementation problems is crucial to have a successful BPC outcome (Kassahun, 2012). It has been stated by extant literature that the upfront expenses are high (Bozman, 1993), problems to connect business system with ICT so that limiting the enabling power of technology to Business process change (Bulkeley, 1992) and redesigning outdated business processes or moving key business processes outside to collaborators (Venkatraman, 1994). 
Numerous organizations today seek after such solutions as BPC without the knowledge of future performance level goals. Thus, processes are connected to intangible targets and main drivers of business issues are insufficiently characterized (Belmonte \& Murray, 1993). For some organizations, making an environment in which Business process change will succeed may be exceedingly troublesome (Grover, et al, 1993). Some contend for more slow takeoffs from conventional practices since managerial developments require significant investment and actuate big strain on the organization (Brown, 1993). As talked about by Guimaraes, Bell \& Marston (1993) in the perspective of organizational change, there is much an organization can do to revamp for fast evolving situations. The changes frequently fall flat in light of the fact that employee habits are not addressed during BPC implementations (Grover, et al, 1993). Succumbing to the burden to quick results, numerous supervisors who executed BPC have a tendency to overlook the monstrous changes in organizational structure, have abused and distanced center directors and lower level representatives, sold off strong organizations, ignored critical innovative work, and prevented the essential modernization of their plants (Cascio, 1993). Executives, who stay after a downsizing, regularly end up living up to expectations in an alternate and less the earth (ibid).

In situations where BPC brought about organization downsizing, the human assets have a tendency to endure solid setbacks (Ehrbar, 1993). Unwilling or not able to adapt to the change, a lot of long-time IS specialists have left the organization (Moad, 1993). More than a large portion of the 1,468 restructured organizations studied by the Society for Human Resource Management reported that workforce productivity either stuck with it or crumbled after the layoffs. A four-year investigation of thirty organizations in the vehicles business uncovered that not very many of the associations actualized 
downsizings in a manner that enhanced their adequacy. Most of the organizations deteriorated relative to their 'pre-downsizing' levels of quality, productivity, and effectiveness indicators (Cascio, 1993). In a similar survey conducted by the American Management Association,the results reveal that less than half the organizations that have downsized report an increase in profits afterward (Greengard, 1993).

Often times, the loss of managerial or technical expertise is immensely costly to an organization, and replacing such lost expertise often is unimaginably expensive (Margulis,1994).Several research studies show that subsequent to downsizing, existing employees become narrow-minded, self-absorbed, and risk averse. This consequentially results in tumbling morale, drops in productivity, and disbelief of management (Cascio, 1993). In multiple of cases, large layoffs of mid level managers have led to fewer layers of management but left in place the spirit of the same organizational structure (Brandt, 1993).

Among other BPC implementation problems indicated in the literature are communications barriers between functional areas (McKee, 1992); lack of leadership and incapacity to handle personal risk and confrontations (Tadler, 1992); strategies formed outside the organization's ability to implement them (Knorr, 1991);in acceptance of the changes by the employees affected (Ryan, 1992); the unexpected vastness of the activity and the disruption to the organization (Huff,1992); the difficulty of balancing the incentives of former performance measures against the required performance measures (Farmer, 1993); some change projects weaken as nervous corporate sponsors pull out at the initial signs of difficulty (Cafasso,1993a); time and again it is not clear to managers whether Business process change is a practical (Freiser, 1992); IS infrastructure in most large organizations are a major impediment to achieving 
immediate benefits (Best,1992); the purging of positions and anxiety over losing jobs are difficult problems (King, 1993); lack of communication between chief information officers and executives (McPartlin, 1992) and management reluctance to commit resources (McPartlin, 1992; Cummings, 1992); major training costs to make the transition (Wen Manager, 1993).

\subsection{Organization Performance}

Whereas the definition for BPC in certain cases is at times stretched outside its commonly accepted features, many organizations have reported significant benefits from their BPC experience (Cafasso, 1993b). For example, Bennet (1994) indicated that an organization in the USA Business process change projects has banished the substantial overtime expenses associated with certain jobs as well as reduced the input of daily operations drastically. Other authors (see for example Goll and Cordovano, 1993) have reported major improvements in customer satisfaction, productivity and profitability at organizations that have undertaken Business process change endeavors.

The projected improvements in performance vary dramatically from organization to organization. Such improvements in productivity, quality, profits and customer satisfaction are expected to improve from around 10 percent to more than 100 percent, depending on where the organization is starting from and the extent of its efforts. Furthermore, when creatively applied the new processes result in dramatic improvements including reduced work space requirements; reduced labor requirements, reduced material handling; improved employee empowerment and morale; and improved communications between operations (Farmer, 1993). BPC demands that teams of people to implement new procedures and programs; besides, it also helps improve relationships with customers and suppliers, empower employees, and improve 
products and processes (Gulden \&Reck, 1992). For example, studies indicate that a poll of IS executives at Computer world Premier 100organizations found that in nearly half of the organizations, Business process change say they are enjoying greater productivity, lower expenses, higher profitability or other benefits (Cafasso, 1993a).Many other similar instances are also declared by the works of Cummings(1993), Fitzpatrick (1992), and Stadler\& Elliot (1992).

As outlined before, there are many possible business benefits from Business process change. For example there is a saying that 'if you can't measure it you can't manage it', and visionary strategy per se is not enough. Therefore, if organizations are to successfully implement large organizational changes, one of which is re-engineering, 'they must use measurement and management systems derived from their strategies and capabilities' (Kaplan and Norton, 1996). The very definitions provided by different authors about re-engineering suggest that performance measurement systems play a significant role in the design and implementation of BPR (Kuwaiti and Kay, 2000). When actually conducted; these organizational benefits hopefully will translate into improved organizational performance. As a result, the organizational performance should be considered the critical measure and dependent variable for studies evaluating the overall benefits from Business process change projects. Organizational performance can be measured in several ways (Steers, 1977; Venkatraman \& Ramanujam, 1986; Snow \& Hrebniak, 1980). Given the extensive variety of benefits from organizational innovativeness research conducted measuring the impact of process innovation on organization performance should use multi-dimensional scales. In this study, the public sector organization performance dimensions of Brignall and Modell shown (2000) like of financial results and resource utilization, quality of service delivery, innovation and competitiveness is also used. 


\section{Hypotheses}

The need for proposing BPC projects has been accepted by many scholars (Farmer, 1993; Grover et al, 1993). According to Monge (1990), organizational theorists have also talked in terms of social and organizational processes. Porter's value chain (1986) and Teece et al's dynamic capabilities (1997) emphasize the competitive advantage of unique processes to the organization. According to Hammer (1996), thinking in terms of business processes provides a new analytic framework that helps break the mold of thinking only based on functional unit. In turn, new team concepts, tools and methodologies are emerging to support the analysis, improvement and management of processes. Therefore as the extent of the BPC expands to include processes which are more strategic to the organization, one should expect to see a parallel increase in problems of implementation and in the degree to which goals and objectives are included in the BPC plan, for fear that changes to some business processes go unaccounted for in the project plans. The nonexistence of this relationship indicates that organizations are not meticulously planning their BPC projects. As a result, it is proposed that:

H1: The degree of changes to strategic processes is positively related to the degree of BPC implementation problems was encountered.

$\mathrm{H} 2$ : The degree of changes to strategic processes is positively related to the degree to which goals and objectives were included in the BPC plan.

It is discussed by many authors (see for example, works of Dagres, 1993, Stadler \& Elliot, 1992) that goals and objectives to be included in BPC implementation plan. Naturally, one should imagine that the more thorough the BPC plans are, the lower the degree to which implementation problems will occur, the greater the likelihood that projects goals and objectives will be achieved, that BPC project benefits will be derived, and that the such change 
project will have a favorable impact on organizational performance. Therefore, I proposed that:

H3: The degree to which goals and objectives were included in the BPC plan is inversely related to the degree the problems are come upon while implementing BPC.

H4: The degree to which goals and objectives were included in the BPC plan is positively related to the degree of BPC:

H4a: project goals and objectives were achieved.

$\mathrm{H} 4 \mathrm{~b}$ : has had an impact on organizational performance.

Likewise, authors like Bozman, 1993; Bulkeley, 1992; Grover, et al, 1993;

Cascio, 1993; and Stadler \& Elliot, 1992, have indicated possible BPC implementation problems and how they may prohibit the organization from accomplishing its goals and objectives, expected benefits, and a positive impact on organizational performance. Therefore, I propose:

H5: The degree to which problems were encountered when implementing BPC is inversely related to the degree of BPC:

H5a: goals and objectives were accomplished.

H5b: has had an impact on organizational performance.

Furthermore, it would be expected that if the BPC goals and objectives are not accomplished, the benefits to the organization from the change effort (BPC) and its favorable impact on organization performance will be minimal. Therefore, I propose that:

H6: The degree to which BPC goals and objectives were accomplished is positively related to the extent $\mathrm{BPC}$ has an impact on organizational performance.

EJBE Vol. 5 No. 1/2015 
Figure 1. The research Model

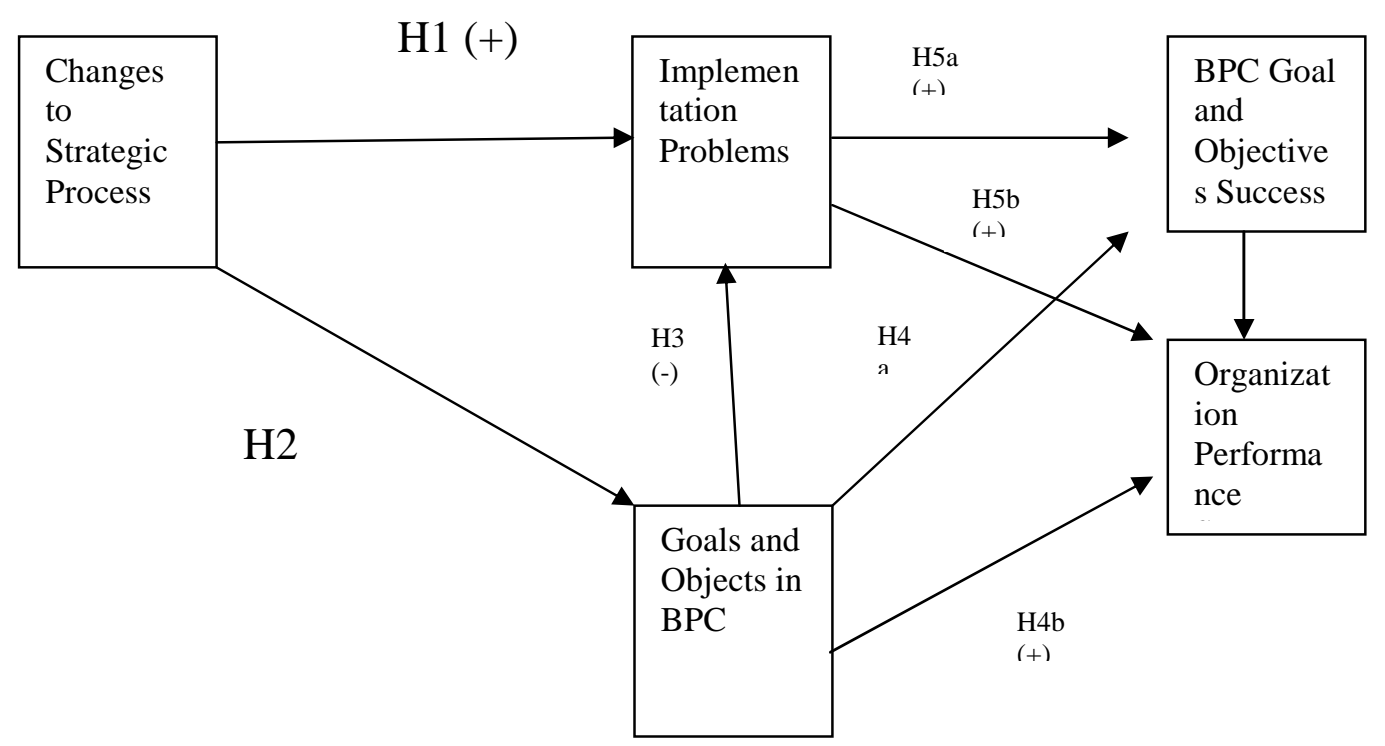

\section{Methodology}

This study is a cross sectional survey study conducted as it allows the collection of data from large populations with a careful design of representative samples, is cost effective, and the anonymity of survey will allow candid responses from respondents (Hansen, Hurwitz and Madow, 1953).

\section{Sampling Method}

A 2 stage sampling method (Cresswell, 2009) is used in the study in which sampling is done sequentially across two or more hierarchical levels. In the first stage public sector institution supervisors in Amhara National Regional State (ANRS) at the top and middle levels was conveniently selected. From among 174,700 employees in the region 6600 employees were officials as per the 2006 report by the ANRS civil service bureau. In the second stage out of the purposively selected 6600 supervisors, a sample of 180 supervisors were 
selected using a simple random method. The researcher assumes that the officials of the region have actively participated in the BPC implementation process of the region. The assumption is government office employees who participated in the design and implementation stage of business process changes have better knowledge of the subject matter under discussion. Then out of these clustered sample population random selection is undertaken to avoid bias in selection of the supervisors.

Questionnaires were personally delivered by the assistance of data collectors to these 180 supervisors. A total of 180 responses (100\% response rate) were received within the specified time, however, 54 had to be discarded due to missing data, invalid responses, and responses based on BPC projects which did not meet specified qualifications. The samples of 126 questionnaires represent a 70 percent out of the total response rate which is considered very satisfactory.

\section{Discussion of Results}

Table 1

\begin{tabular}{|l|l|l|l|}
\hline & Degree of Strategic change to processes & Mean & SD \\
\hline 1 & Customer Satisfaction & 3.5 & 0.88 \\
\hline 2 & Stakeholder Satisfaction & 4.5 & 0.67 \\
\hline 3 & Service Quality management & 4 & 0.62 \\
\hline 4 & Employee Satisfaction management & 3 & 0.99 \\
\hline 5 & Project management & 4 & 0.75 \\
\hline 6 & Strategic planning process & 4 & 0.59 \\
\hline 8 & Quality of work life & 4 & 0.77 \\
\hline 9 & $\begin{array}{l}\text { improved level of organizational openness and } \\
\text { transparency }\end{array}$ & 4 & 0.99 \\
\hline 10 & Organizational culture & 3.8 & 0.22 \\
\hline
\end{tabular}

EJBE Vol. 5 No. 1/2015 


\section{Process Change Elements}

As can be seen in Table 1, on the average, business processes that have a strategic impact on the organizations have changed to the greatest magnitude. Table 2 shows that BPC project plans seem to include to the highest degree the goals and objectives of focusing on organizational performance. Table 3 suggests that on the average, organizations who have implemented BPC projects have accomplished, at least to a moderate degree, some important BPC project goals and objectives such as operating effectively throughout all organizational units, harmony on changes made, and focused on end results and objectives. Despite the fact that some of the items show reasonably large standard deviations indicating considerable organization to organization variance around the mean, organizations are accomplishing all the enlisted goals and objectives.

Table 2

\begin{tabular}{|l|l|l|l|}
\hline & $\begin{array}{l}\text { Degree to which BPC goals and objectives } \\
\text { (Process Performance) were included in the plan }\end{array}$ & Mean & SD \\
\hline 1 & Reduction in process time & 4.5 & .62 \\
\hline 2 & Reduction in cost & 3.8 & .66 \\
\hline 3 & flexibility introduced to service delivery processes & 3.2 & .70 \\
\hline 4 & communication plans & 2.8 & .99 \\
\hline 5 & change management & 2.7 & 1.1 \\
\hline 6 & customer focus in performance & 3.3 & .70 \\
\hline 7 & application of the right ICT & 3.0 & \\
\hline 8 & employee harmony & 2.78 & .98 \\
\hline 9 & employee empowerment & 3.77 & .87 \\
\hline
\end{tabular}

As per Table, 4 discovering that the BPC project is much larger than originally expected, upsetting project plans by making mistakes under pressure to produce quick results, and top management reluctance to commit the necessary funds for the project on the average the most severe planning problems. In 
addition, on the average, the harshest problems are the absence of incentive schemes, delayed or no regulatory support, incompetent leadership, lack of knowledge of future performance level goals, lack of employee empowerment, and the gap of communication among the officers at different levels. The level of implementation costs of BPC, lack of commitment to avail resources, in existence of employee training, and employee layoffs has on average been rated as less a problem than lack of top management commitment to provide funds for the BPC project implementation. BPC projects seem to produce lots of problems which may be considered as side effects of such change endeavors. Among the most severe side effects are making mistakes under pressure to produce quick results, creating an unfriendly working environment, difficulty in implementing BPC due to communication barriers, and lack of communication between top management and ICT offices. Lastly, some BPC problems are due to a basic lack of results such as projects falling short on expected benefits and management frustration with slow bottom line results.

Table 3

\begin{tabular}{|l|l|l|l|}
\hline & $\begin{array}{l}\text { Degree to which BPC goals and objectives } \\
\text { (Process Performance) were achieved }\end{array}$ & Mean & SD \\
\hline 1 & Reduced process time & 2.78 & 0.94 \\
\hline 2 & Reduced cost per service & 2.9 & 1.2 \\
\hline 3 & flexible service delivery processes all employees & 3 & 0.8 \\
\hline 4 & $\begin{array}{l}\text { good communication between acquired } \\
\text { acqued among }\end{array}$ & 2.88 & 0.96 \\
\hline 5 & $\begin{array}{l}\text { high level of consensus on the BPC project } \\
\text { staff }\end{array}$ & 2.92 & 0.98 \\
\hline 6 & good customer satisfaction & 3.2 & 0.75 \\
\hline 7 & Right ICT in place & 2.68 & 0.77 \\
\hline 8 & employee harmony & 2.78 & 0.98 \\
\hline 9 & empowered employee & & Page \\
\hline
\end{tabular}

EJBE Vol. 5 No. $1 / 2015$ 
Process Change Elements

Table 4

\begin{tabular}{|l|l|l|l|}
\hline & BPC Implementation Problems & Mean & SD \\
\hline 1 & High upfront expenses & 2.4 & 1.5 \\
\hline 2 & a tendency to focus on the innovation side & 3.5 & 1.2 \\
\hline 3 & redesigning business processes are outdated & 3.6 & 0.88 \\
\hline 4 & lack of knowledge of future performance level goals & 3.78 & 0.56 \\
\hline 5 & slow takeoffs from conventional practices & 3.64 & 0.65 \\
\hline 6 & no or in existence of employee training & 2.55 & 0.55 \\
\hline 7 & lack of commitment to avail resources & 2.44 & 0.75 \\
\hline 8 & in existence of change to organization structures & 3.2 & 0.57 \\
\hline 9 & lack of employee empowerment & 3.66 & 0.99 \\
\hline 10 & unnecessary layoffs of key employees & 2.34 & 0.66 \\
\hline 11 & downsizing/disregarding strategic units & 3.1 & 0.99 \\
\hline 12 & Incompetent leadership & 3.99 & 0.66 \\
\hline 13 & Communication barriers & 3.25 & 1 \\
\hline 14 & loss of employee morale & 3.33 & 0.88 \\
\hline 15 & Lack of employee trust & 3.6 & 0.99 \\
\hline 16 & absence of incentive schemes & 4 & 1 \\
\hline 17 & delayed or no regulatory support & 4.5 & 0.68 \\
\hline
\end{tabular}

Table 5 shows that, on the average, the greatest benefits from BPC project implementation are reported to be improved customer satisfaction and improved employee morale and productivity. Improvements in the use of information technology to address customer needs have on the average occurred only to a small degree. As compared to others, the relatively large standard deviations indicate that each organization in the region shows significant differences with regard to their BPC derived benefits. On the other hand, on the average the organizations under study are getting all the benefits listed at least to a minor degree.

Based on the results indicated on Table 5, BPC has had, on the average, a significant impact on organizational performance. Hence, on the average, such 
change effort has helped to a reasonable degree the areas of employees' development, cost reduction, accountability, transparency, innovative work performance, reduced corruption and customer service satisfaction. By the same token, the relatively large standard deviations indicate that the impact on organization performance varies significantly from organization to organizations implying that its implementation can be quite risky depending on the organization, application, and project management circumstances.

Table 5

\begin{tabular}{|l|l|l|l|}
\hline & $\begin{array}{l}\text { Organization performance ( Organizational } \\
\text { outcome and Impact) }\end{array}$ & Mean & SD \\
\hline 1 & $\begin{array}{l}\text { Increased operational efficiency(decreased cycle } \\
\text { time, inventory) }\end{array}$ & 2.3 & .97 \\
\hline 2 & Increase Customer satisfaction & 3.6 & 1.2 \\
\hline 3 & Increased accountability & 2.75 & 0.98 \\
\hline 4 & Increased transparency & 2.69 & 0.77 \\
\hline 5 & Increase in the quality customer service & 3.2 & 1 \\
\hline 6 & Innovative service delivery & 3 & 1 \\
\hline 7 & Reduced budget consumption & 2.79 & 1.1 \\
\hline 8 & Increased competitiveness & 2.75 & 0.84 \\
\hline 9 & Improved employee morale and productivity & 3.55 & 1.3 \\
\hline 10 & Reduced corruption & 3.78 & 1.2 \\
\hline 11 & Improved ICT application & 2.72 & 0.98 \\
\hline
\end{tabular}

\section{Hypothesis Testing}

As shown in Table 6 below, the major variables correlation matrix, the hypotheses proposed in this study are revised to show the correlation coefficients for the accepted hypotheses. The following hypotheses were corroborated at the .01 significance level or better:

H1: The degree of changes to strategic processes is positively related to the degree BPC implementation problems was encountered. 
$\mathrm{H} 2$ : The degree of changes to strategic processes is positively related to the degree to which goals and objectives were included in the BPC plan.

H4: The degree to which goals and objectives were included in the BPC plan is positively related to the degree BPC:

H4a: project goals and objectives were achieved.

H4b: has had an impact on organizational performance.

The following hypotheses have not been corroborated:

H3: The degree to which important goals and objectives were included in the $\mathrm{BPC}$ plan is inversely related to the degree problems were encountered while implementing BPC.

H5a: The degree to which problems were encountered when implementing $\mathrm{BPC}$ is inversely related to the degree BPC goals and objectives were accomplished.

H5b: The degree to which problems were encountered when implementing BPC is inversely related to the degree BPC has had an impact on organizational performance. 


\begin{tabular}{|c|c|c|c|c|c|c|}
\hline & & $\begin{array}{l} \\
\text { Change } \\
\mathrm{s} \quad \text { to } \\
\text { Strategi } \\
\mathrm{c} \\
\text { Process } \\
\text { es }\end{array}$ & $\begin{array}{l}\text { The } \\
\text { degree } \\
\text { of } \\
\text { chang } \\
\text { es to } \\
\text { goals } \\
\text { and } \\
\text { object } \\
\text { ives }\end{array}$ & $\begin{array}{l}\text { The } \\
\text { degree } \\
\text { proble } \\
\text { ms in } \\
\text { imple } \\
\text { menti } \\
\text { ng } \\
\text { BPC }\end{array}$ & $\begin{array}{l}\text { the } \\
\text { degree } \\
\text { to } \\
\text { project } \\
\text { goals } \\
\text { and } \\
\text { objectiv } \\
\text { es were } \\
\text { achieved }\end{array}$ & $\begin{array}{l}\text { The degree } \\
\text { on } \\
\text { Organizatio } \\
\text { nal } \\
\text { performanc } \\
\text { e }\end{array}$ \\
\hline $\begin{array}{lll}\text { Changes } & \text { to } & \text { Strategic } \\
\text { Processes } & & \\
\end{array}$ & $\begin{array}{l}\text { Pearson } \\
\text { Correlation } \\
\text { Sig. (1-tailed) } \\
\text { N }\end{array}$ & $\begin{array}{l}1 \\
126\end{array}$ & & & & \\
\hline $\begin{array}{l}\text { The degree of changes to } \\
\text { goals and objectives }\end{array}$ & $\begin{array}{l}\text { Pearson } \\
\text { Correlation } \\
\text { Sig. (1-tailed) } \\
\mathrm{N}\end{array}$ & $\begin{array}{l}.112 \\
.106 \\
126\end{array}$ & $\begin{array}{l}1 \\
126\end{array}$ & & & \\
\hline $\begin{array}{l}\text { The degree problems in } \\
\text { implementing BPC }\end{array}$ & $\begin{array}{l}\text { Pearson } \\
\text { Correlation } \\
\text { Sig. (1-tailed) } \\
\mathrm{N}\end{array}$ & $\begin{array}{l}.053 \\
.277 \\
126\end{array}$ & $\begin{array}{l}-.180^{*} \\
.022 \\
126\end{array}$ & $\begin{array}{l}1 \\
126\end{array}$ & & \\
\hline $\begin{array}{ll}\text { the degree to project } & \text { goals } \\
\text { and objectives } & \text { were } \\
\text { achieved } & \end{array}$ & $\begin{array}{l}\text { Pearson } \\
\text { Correlation } \\
\text { Sig. (1-tailed) } \\
\mathrm{N}\end{array}$ & $\begin{array}{l}.359^{* *} \\
.000 \\
126\end{array}$ & $\begin{array}{l}.182^{*} \\
.021 \\
126\end{array}$ & $\begin{array}{l}-.090 \\
.158 \\
126\end{array}$ & $\begin{array}{l}1 \\
126\end{array}$ & \\
\hline $\begin{array}{l}\text { The degree on } \\
\text { Organizational performance }\end{array}$ & $\begin{array}{l}\text { Pearson } \\
\text { Correlation } \\
\text { Sig. (1-tailed) } \\
\mathrm{N}\end{array}$ & $\begin{array}{l}-.104 \\
.123 \\
126\end{array}$ & $\begin{array}{l}.365^{* *} \\
.000 \\
126\end{array}$ & $\begin{array}{l}-.205^{*} \\
.011 \\
126\end{array}$ & $\begin{array}{l}.148^{*} \\
.049 \\
126\end{array}$ & $\begin{array}{l}1 \\
126\end{array}$ \\
\hline & $\begin{array}{l}\text { Sig. (1-tailed) } \\
\mathrm{N}\end{array}$ & $\begin{array}{l}.082 \\
126\end{array}$ & $\begin{array}{l}.379 \\
126\end{array}$ & $\begin{array}{l}.033 \\
126\end{array}$ & $\begin{array}{l}.026 \\
126\end{array}$ & $\begin{array}{l}.387 \\
126\end{array}$ \\
\hline \multicolumn{7}{|c|}{ **. Correlation is significant at the 0.01 level (1-tailed) } \\
\hline *. Correlation is significant $\mathrm{c}$ & 0.05 level & & & & & \\
\hline
\end{tabular}

EJBE Vol. 5 No. 1/2015 


\section{Conclusions}

As per the results of this research discussed above, we can conclude that organizations are not emphasizing some of the most important activities and tasks recommended scholars mentioned in the literature as foundations for BPC. Such basic foundations for BPC are the notion towards time as a significant weapon, changes to strategic processes, and the application of the appropriate ICT. For that reason, it can be inferred that these disregards are major reasons for the failure of many of the BPC project outcomes.

On the average, the problems most frequently fall in with while implementing BPC appear to be basic and difficult to tackle in practice such as communication barriers, the unexpectedly increased magnitude of the required BPC effort, its disruption to the day to day operations, failure to get the desired performance outcomes and outputs, and lack or reluctance of commitment by the leadership of organizations the funds indispensable for the implementation of BPC efforts. It has been asserted by gurus like Hammer and Champy (1993) that ICT is the enabler of reengineering, in organizations under study an observation is made that there is lack of consensus between top officials and information system experts which contributed to the ineffectiveness if not demise of such change projects. While it has been observed that BPC deliver major benefits and meaningful impact on organizational performance, all the problems reported seem to outweigh such benefits. Hence it can be argued that success factors like top management commitment, well organized BPC project team and plans, focus on outcomes, sufficient resources and fund, and well defined communications plan will positively impact organizations undertaking BPC projects. Furthermore, the creation of team spirit and good working environment can play a paramount significance towards the above stated end. Though the above stated success factors, on the average, have received the 
highest importance ratings, factors which received with lower ratings but larger standard deviations, it is believed, has to be further investigated in certain circumstances with the fact that some of the respondents see them as very important.

It has been found out that the hypothesis which proposed an opposite relationship between the degree to which goals and objectives are included in the BPC plan and the degree to which implementation problems were encountered implies that the wholeness of a plan of action does not warranty the existence of implementation problems. This could infer that having a comprehensive BPC implementation plans incorporating a wider collection of goals and objectives may indicate project complexity which in turn may increase the intensity and variety of the problems. Conversely, rejecting the hypothesis which states that the degree to which goals and objectives were achieved is inversely related to the degree of implementation problems encountered can be surmised in the same manner above.

To accept the first two hypotheses implies that organizations which broaden the scope and strategic nature of their BPC projects will face greater implementation problems though they have a tendency to make bigger BPC project plans to account for the greater extent of process changes and consequent outcomes.

The extent to which BPC goals and objectives are accomplished is strongly related to the benefits the organization derives from the BPC project, and also related to the extent the BPC project has an impact on organization performance. The extent to which benefits are derived is also positively related to organization performance.

Generally, it is necessary that higher officials should not join battle with BPC projects if it is not a necessity to strategically win or reemerge the organization. 
Otherwise, before entering into the BPC project it is a requisite to improve organizational learning capability through better communication channels, reduced bureaucracy, empowering employees, continuous improvement, team spirit, and development of learning environment so that in developing countries where resources are a luxury damages could be minimized if not averted.

While it is believed that the research major objectives were accomplished, the study is not without limitation and hence could trigger opportunities for future research. Since the survey method in ANRS officials is used to answer the questions posed in the research, replication may be required using a larger sample in a wider geographical location. Besides, to increase generalizability of the research, a mixed method can be conducted to achieve causality of the findings of this research. Nonetheless, the measures used internal reliability was found to be satisfactory, more statistical analysis have to be undertaken to identify sub-constructs and assess their reliability. Furthermore, it demands for longitudinal studies and mixed method designs to further investigate and validate the cause and effect relationships between variables. Also conducting the research with a larger sample size will enable for multivariate statistical analysis so that possible mediating and moderating variables among the independent variables could be identified and validated. 


\section{References}

Abdolvand, Neda. Albadvi, Amir. Ferdowsi, Zahra. (2008). Assessing readiness for business process re- engineering, Business Process Management Journal, Vol. 14 No. 4, pp. 497-511.

Ahmed, Hartini., Francis, Arthur. Zairi, Mohammed. 2007. Business process re-engineering: critical success factors in higher education, Business Process Management Journal,Vol. 13, No. 3, pp. 451-469.

Al-Mashari, Majid.Zairi, Mohammed. 1999. BPR implementation process: an analysis of key success and failure factors, Business Process Management Journal, Vol. No.1, pp.87-112.

Amoroso, Donald (1998). Developing a Model to Understand Re-engineering Project Success, IEEE. Antwi, Kwabana. AnalouiAygekum,

Nana. (2008). Public Sector reform in Sub-Saharan Africa. What can be learnt from the civil service performance improvement program in Ghana? Public Administration and Development, 28, pp. 253-264.

Attaran, Mohsen. (2000). Why does re-engineering fail? A practical guide for successful implementation, Journal of management development. Vol. 19, No. 9, pp. 794-801

Best, J. (1992). A Dual Approach.CIO, The Magazine for Information Executives, p. 28-29.

Belmonte, Rocco. Murray, Richard. (1993). Getting Ready for Strategic Change".Information Systems Management, Vol. 10, No. 3, p. 23-29 Brandt R. (1993).The Virtual Corporation.Business Week, p. 99-102.

Bozman, S. (1993). Downsizing, Rightsizing, Something sizing.Computer World, p.6-10,

Brignall, Stan. Modell, Sven, (2000). An institutional perspective on Performance measurement and management in the 'New Public Sector. Management Accounting Research 11 (3), 281-306.

Brown, Warren. (1993). Leading the Way to Faster New Product Development. Academy of Management Executive, Vol. 7, No. 1, p. 36-47.

Bulkeley Duncan. (1992). Anderson Reengineers Big Business. Systems 
Process Change Elements

Integration Business Cafasso, Rosemary. 1993a. Rethinking

Reengineering.Computer World, p. 102-105.

Cafasso, Rosemary. (1993). Jean Genies.Computer World, p. 99-102.

Cascio, Wayne. (1993). Downsizing: What do we know? What have we

learned? Academy of Management Executive, Vol. 7, No. 1, p.

95-104.

Cheng, Tai Chiu Edwin. Chiu, Ida. (2008), Critical Success Factors of

Business Process Re-engineering in the Banking Industry,

Knowledge and Process Management, Volume 15 Number 4 pp

258-269.

Creswell, John. (2009). Research Design: Qualitative, Quantitative, and Mixed

Methods Approaches (Kindle Locations 4139-4140). Sage

Publications.

Cummings, Joanne. (1992). Reengineering Falls Short of Expectations, Study

Finds". Network World, p.27.

Dagres, Todd.(1993). Network Reengineering for Competitive Advantage.

White Paper, 1993.

Davenport, Thomas. Short, James. (1990). The New Industrial Engineering:

Information Technology and Business Process Redesign". Sloan

Management Review, Vol. 31, No. 4, p.11-27.

Debela,Tesfaye. (2009).Business process re-engineering in Ethiopian public organizations: the relationship between theory and practice, Journal of Business and Administrative Studies, Vol. 1, No. 2.

Earl, Michael. Sampler, Jeffrey. Short, John.(1995). Strategies for Business

Process Re-engineering: Evidence from field studies, Journal of management Information Systems, Vol. 12, No. 1, pp. 31-56.

Ehrbar, Al. (1993). Reengineering Gives Firms New Efficiency, Workers the Pink Slip". The Wall Street Journal, Vol. CCXXI, No. 51.

Farmer, R. (1993). Reengineering the Factory.InAPICSeds, performance advantage pp. 38-42.

Fitzpatrick W. (1992).Information Management.Journal of the American Society of CLU and ChFc, p. 34-35.

Fragoso, Jaime. 2015.Business Process Reengineering in Government Agencies: Lessons from anExperience in Mexico, Journal of Service Science and Management, 2015, Vol.8, PP. 382-392. 
Freiser, Theodore J. (1992). The Right Start for Business

Reengineering".Information Strategy: TheExecutive's Journal, Vol.9 p. 26-30.

Greengard, Samuel. (1993). Don't Rush Downsizing: Plan, Plan, and Plan. Personnel Journal, 72(11), p. 64-76.

Guimaraes, Tor. Bell, R. Marston R. 1993. Organizing for Innovation. $4^{\text {th }}$ International Forum on Technology Management, Berlin, Germany.

Gebrekidan, Adebaby. (2011). Promoting and strengthening professionalism in the civil service: The Ethiopian case, A paper presented on the workshop on "promoting professionalism in the public service: Strengthening the role of Human Resource Managers in the public sector for the effective implementation of the charter for public Service in Africa, 14- 18 March 2011 Addis Ababa, Ethiopia.

Goll O. Cordovano F. (1993). Construction Time Again”. CIO, The Magazine for Information Executives, p. 32-36.

Grover, Varun. Teng, James. Fiedler, K.D.:"'Information Technology Enabled Business Process Redesign: An Integrated Planning Framework. OMEGA, Vol. 21, No. 4, p. 433-447, 1993.

Gulden K. Reck H. (1992). Combining Quality and Reengineering Efforts for Process Excellence”. Information Strategy: The Executive's Journal.

Hailemariam, Getachew. Brocke,Janvom. (2011). What is sustainability in Business Process Management? A theoretical Framework and its Application in the public sector in Ethiopia in Brocke, Jan vom (eds) Business Process Management Workshops, Lecture notes in Business Information Processing. Vol.66, PP.489-500.

Hammer,Michael.Champy, James. (1993). Re-engineering the Corporation: a Manifesto for Business Revolution, Nicholas Brearley Publishing, London.

Hammer, Michael. Stanton, Steven.(1995). The Re-engineering Revolution, HarperCollins Publishers, New York.

Hammer, Michael. (2010). What is business process management? In JvomBrocke and M Rosemann (eds.), Handbook on business process management, vol. 1, Springer.

Hansen,Morris. Hurwitz, William. Madow, William, (1953). Sample Survey Methods and Theory: Volume 1, Methods and Applications. 
John Wiley \& Sons, INc, Canada.

Harmon, Paul. (2010). The scope and evolution of business process management in Brocke,Jan vom and Rosemann, Michael (eds.), Handbook on Business Process Management 1, International Handbooks on Information Systems, Springer-Verlag Berlin Heidelberg. PP 37-81.

Herzog, Natasa.Tonicha,Stefno.Polajnar, Andrie. (2009).Linkages between manufacturing strategy, benchmarking, performance measurement and business process re-engineering. Computers and Industrial Engineering, Vol. 57, pp. 963-975.

Huff L. (1992). Reengineering the Business.Business Quarterly, p. 38-42.

Kaplan, Robert.Norton, David.(1996), The Balanced Score Card: Translating strategy into action, Harvard Business School press, Boston, MA.

Kaplan R. and Norton D. (2008), The Execution Premium: linking strategy to operations for competitive advantage, Harvard Business School press, Boston, MA.

Kassahun, Asmare. (2012). The Effect of Business Process Reengineering On Public Sector Organization Performance (A Developing Economy Context), (Doctoral Thesis Of Philosophy).

Kettinger, William. Grover, Varun. (1995). Special section: toward a theory of business process change management. J Manage Information Systems Vol. 12 Issue 1.

Kettinger ,William. Teng, James. (1998), Aligning BPR to strategy: A framework for analysis, Long Range Planning, Vol.1, PP. 93 to 107.

Knorr, Robert O. (1991). Business Process Redesign: Key to Competitiveness. The Journal of Business Strategy, p. 48-51.

King, Julia. (1993). Reengineering Repercussions. Computer World, p. 149 -150 .

Kuwaiti, Mohammed. Kay, John.(2000), The role of performance measurement in business process re-engineering. International journal of operations and production management, Vol. 20, No. 12, pp. 1411-1426.

Lockamy III A. and Smith W. (1997), A strategic alignment approach for effective business process re-engineering: linking strategy, processes and customers for competitive advantage, International journal of 
production economics, Vol. 50, pp. 141-153.

MacPartlin P. (1992). Seeing Eye to Eye on Re-engineering. Information Week, p. 74.

McAdam, Rodney. Donaghy, John. 1999. Business process re-engineering in the public sector, Business Process Management Journal, Vol. 5 Issue 1 pp. $33-52$.

McKee, Daryl. (1992). An Organizational Learning Approach to Product Innovation. Journal of Product Innovation Management, Vol. 9, p. 232-245.

Mengesha, Getachew. Richard, Common. (2007). Public Sector Capacity Reform in Ethiopia, a Tale of Success in Two Ministries. Public Administration and Development Volume 27, Issue 5, pages 367 -380 .

Moad, Jeff. (1993). Does Reengineering Really Work. Datamation, p. 22-28.

Nunally, JumC.1978. Psychometric Theory, Second Edition. McGraw-Hill, New York, NY, PP, 367-380.

Piercy, Nial. Phillips, Wendy. Lewis, Michael. (2013). Change management in the public sector: the use of cross-functional teams, Production Planning \& Control, Vol. 24, No. 10-11, 976-987.

Porter, Michael. (1985) Competitive Advantage: Creating and Sustaining Superior Performance, New York: The Free Press.

Ryan, Hugh. (1992). Managing Change. Information Systems Management, p. 60-62.

Roberto,Montanari. Eleonara, Bottani.2015. Improving the efficiency of public administrations through business process reengineering and simulation, Business Process Management Journal, Volume 21, Number 2, pp. 419-462(44).

Rosemann,Micheal.Brocke, Jan vom.2010. The Six Core Element of Business Process Management. In: Brocke, Jan vom. Rosemann, Michael (eds) Handbook on Business Process Management, Vol 1Springer, Heidelberg.

Salamn, Ahmed. (2004). Elusive Challenges of e-change management in developing countries. Business Process Management Journal, Vol.16,No.2.

Steers, Richard. (1977). Organizational Effectiveness: A Behavioral View. The 
Goodyear series in management and organizations, Santa Monica,CA: Goodyear Publishing.

Snow, Charles. Hrebniak, Lawrence.(1980). Strategy, distinctive competence, and organizational performance. Administrative Science Quarterly, Vol. 25, p.317-335.

Stadler, D.A. \& Elliot, S.A.:“Remake Your Business”. Inform, February, p. 12 $-17,1992$.

Teece, David. Pisano,Pisano.Shuen, Amy. 1997. Dynamic Capabilities and Strategic Management. Strategic Management Journal 18, PP. 509-33.

Theng, James. Yap, Chi-Sing.Seah, Kin-Lee.2000.Business Process Re -engineering in thePublic Sector: The Case of the Housing Development Board in Singapore. Journal of Management Information Systems, Vol. 17, No. 1, pp. 245-270.

Tsang, E.: "Business Process Reengineering and Why It Requires Business Event Analysis". CASE Trends, p. 8-15, March 1993.

Teklegiorgis H., and Amare, G. (2007), Success stories: Public Sector Capacity in Ethiopia, a consultancy report to Ministry of Capacity Building, Ethiopia.

UNDP, (2007), Ethiopia: final evaluation of UNDP program.

Venkatraman N, Venkat. (1994). IT-Enabled Business Transformation: From

Automation to Business Scope Redefinition. Sloan Management

Review, Vol. 35, No. 1, p. 73-87. 